\title{
Wojciech Odrowąż-Sypniewski
}

\section{Status posła „zawieszonego" w klubie poselskim (parlamentarnym) ${ }^{1}$}

Status of a "suspended" Deputy in Deputies' (parliamentary) club (WAKiU-227/18): Suspension of the membership in Deputies' (parliamentary) club is not the same as loss of membership, hence it does not cause changes in the composition of a club. Due to the fact that the Standing Orders of the Sejm do not include any provisions concerning the status of a Deputy, whose membership in the club has been suspended, effects of such suspension should be perceived solely in the sphere of club's internal matters. The suspended Deputy, until a information about a loss of his/her club membership is submitted to the Marshal of the Sejm, shall be treated by Sejm authorities as a member of the club.

Keywords: Deputies'club, Deputy, Standing Orders of the Sejm

Słowa kluczowe: $\quad$ klub poselski, poseł, regulamin Sejmu

Ekspert ds. legislacji BAS; wojciech.sypniewski@sejm.gov.pl.

\section{Przedmiot opinii}

Przedmiotem opinii jest analiza kwestii prawnych związanych $\mathrm{z}$ wątpliwością dotyczącą statusu posła, który „zawiesił” swój udział w klubie poselskim (parlamentarnym), względnie „zawieszenie” członkostwa wynika z rozstrzygnięcia władz klubu. Chodzi również o ustalenie, jakie są konsekwencje takiego „zawieszenia" dla wykonywania praw członka komisji sejmowej, której skład wyznacza zasada parytetu (w szczególności Komisji Etyki Poselskiej oraz Komisji do Spraw Unii Europejskiej).

1 Opinia sporządzona 31 stycznia 2018 r. na zlecenie zastępcy Szefa Kancelarii Sejmu; BAS-WAKiU 227/18. 


\section{Zasady tworzenia zrzeszeń parlamentarnych}

Cechą charakterystyczną unormowań określających formy organizacyjne zrzeszeń parlamentarnych jest swoista „dwutorowość" regulacyjna. Zasady organizacji klubów, kół i zespołów poselskich, senatorskich oraz parlamentarnych ustanowione zostały zarówno w regulaminach izb, jak i w ustawie z 9 maja $1996 \mathrm{r}$. o wykonywaniu mandatu posła i senatora (Dz.U. 2016, poz. 1510, ze zm.; dalej: ustawa lub u.w.m.p.s.). Swoista „równoległość” unormowań zawartych w regulaminach i ustawie, jak również ich lakoniczność mają istotny wpływ na ustalenia dotyczące tożsamości ustrojowej tych zrzeszeń.

Zgodnie z ustawą zasady tworzenia przez posłów w Sejmie klubów, kół lub zespołów poselskich określa regulamin Sejmu (art. 17 ust. 1 u.w.m.p.s.). Analogiczne uprawnienie przysługuje senatorom, którzy na zasadach określonych w regulaminie Senatu mogą tworzyć w Senacie kluby, koła lub zespoły senackie (art. 17 ust. 2 u.w.m.p.s.). Ponadto ustawa przewiduje, że: [p] osłowie wraz $z$ senatorami moga tworzyć wspólne kluby, koła lub zespoły parlamentarne (ust. 3) oraz zastrzega ochronę prawną - na zasadach przewidzianych dla dóbr osobistych - nazw, skrótów nazw i symbolów graficznych klubu i kól, o których mowa w jej przepisach (ust. 4). Przepisy ustawy określają również zasady tworzenia biur służących obsłudze klubów i kół poselskich, senatorskich i parlamentarnych.

Regulamin Sejmu stanowi, że posłowie mogą tworzyć w Sejmie kluby poselskie lub koła poselskie oparte na zasadzie politycznej (art. 8 ust. 1). Klub może utworzyć co najmniej 15 posłów (ust. 2), koło - 3 posłów (ust. 3). Poseł może należeć tylko do jednego klubu poselskiego lub koła poselskiego (ust. 4). Kluby lub koła poselskie mogą na zasadzie wzajemnych porozumień ustanawiać wspólną reprezentację w Konwencie Seniorów (ust. 4). Obok klubów i kół posłowie mogą tworzyć w Sejmie zespoły „zorganizowane na innych zasadach niż określone w ust. 1". Władze wszystkich zrzeszeń poselskich są zobowiązane do podania do wiadomości Marszałka Sejmu składów osobowych zrzeszeń oraz ich regulaminów (statutów) wewnętrznych (art. 8 ust. 7 regulaminu Sejmu). Zbieżne zasady przewiduje regulamin Senatu, przy czym klub może utworzyć 7 senatorów, a koło - 3 senatorów (art. 21 regulaminu Senatu).

Porównując unormowania regulaminowe z regulacją ustawową, trudno nie dostrzec, że jedynie w przypadku zrzeszeń poselskich sformułowane zostały reguły określające zasady ich tworzenia. Ustawa milczy na temat zasad organizowania klubów, kół i zespołów parlamentarnych, ograniczając się do stwierdzenia, że zrzeszenia te mogą być tworzone przez posłów wraz z senatorami. Konsekwencją lakoniczności regulacji ustawowej jest konieczność sięgnięcia - w drodze analogii - do regulaminowych rozwiązań odnoszących się do zrzeszeń poselskich w celu ustalenia minimalnej liczby parlamentarzystów, którzy mogą utworzyć klub lub koło parlamentarne. Praktyka ostatnich kilku kadencji Sejmu i Sena- 
tu wskazuje, że za klub parlamentarny uznawane są zrzeszenia parlamentarne, które spełniają odnoszący się do danej formy zrzeszenia warunek minimalnej liczebności parlamentarzystów tylko jednej z izb². Niezależnie od sposobu rozstrzygania dylematów związanych z liczebnością klubów i kół parlamentarnych, nierozwiązana na gruncie dogmatycznym pozostaje kwestia braku obowiązku notyfikowania organom izb faktu utworzenia tych podmiotów oraz problemy związane $\mathrm{z}$ rozstrzyganiem wątpliwości związanych $\mathrm{z}$ ich statutami wewnętrznymi (przepisy ustawy nie ustanawiają obowiązku przedstawiania organom izb statutów wewnętrznych klubów i kół parlamentarnych). W praktyce parlamentarnej - w omawianym przypadku - stosowane są przepisy dotyczące klubów i kół poselskich. De lege ferenda należałoby jednak postulować jednoznaczne unormowanie tych zagadnień.

\section{„Zawieszenie" członkostwa w zrzeszeniu poselskim (parlamentarnym)}

1. Punktem wyjścia dla analizy skutków prawnych „zawieszenia” członkostwa w zrzeszeniu parlamentarnym (pojęciem tym dla uproszczenia obejmuję kluby, koła i zespoły poselskie oraz parlamentarne) musi być konstatacja, że przepisy ustawy i regulaminu Sejmu nie określają żadnych szczególnych reguł odnoszących się do takiej sytuacji, a nawet nie znają (nie posługują się) takim pojęciem. W tym kontekście instytucję „zawieszenia” członkostwa wiązać należy z wykonywaniem praw członka zrzeszenia poselskiego (parlamentarnego) wynikających z jego statutu wewnętrznego.

Zbiór analizowanych przypadków obejmuje - jak się wydaje - dwie podstawowe kategorie. Pierwszą tworzyć będą sytuacje, w których posłowie samodzielnie „zawieszają” swój udział zrzeszeniu parlamentarnym. Tego rodzaju oświadczenie postrzegać należy jako jednostronną deklarację woli o powstrzymaniu się od wykonywania praw członka danego zrzeszenia parlamentarnego. Jeżeli możliwość złożenia takiego oświadczania przewidziana jest w statucie wewnętrznym zrzeszenia, wówczas wywoływać ono będzie przewidziane w nim skutki prawne (które jednak nie mogą wykraczać poza sferę, która może być regulowana tym aktem). W sytuacji, gdy statut nie przewiduje takiej możliwości, wówczas oświadczenie posła stanowić będzie wyłącznie deklarację polityczną, która bezpośrednio nie wywoła żadnych skutków prawnych, jednak rodzić może skutki pośrednie (konsekwencją braku aktywności na forum zrzeszenia mogą być sankcje przewidziane w statucie wewnętrznym). Druga kategoria przypadków obejmuje sytuacje, w których zawieszenie członkostwa

2 K. Grajewski, Uwagi do art. 17 [w:] K. Grajewski, J. Stelina, P. Uziębło, Komentarz do ustawy o wykonywaniu mandatu posła i senatora, Warszawa 2014, s. 234. 
następuje na skutek rozstrzygnięcia władz zrzeszenia lub innych przewidzianych w statucie organów zrzeszenia (np. komisji dyscyplinarnej). W takich sytuacjach zawieszenie członkostwa stanowi sankcję dyscyplinarną zastosowaną wobec członka zrzeszenia przez uprawniony organ zrzeszenia, która polega na czasowym pozbawieniu go możliwości wykonywania praw członka zrzeszenia wynikających ze statutu wewnętrznego. W omawianych przypadkach zawieszenie członka zrzeszenia dotyczyć może wyłącznie sfery wewnętrznej (interiów) zrzeszenia i nie może wykraczać poza zakres praw i obowiązków regulowanych statutem wewnętrznym.

2. Zgodnie z art. 8 ust. 7 regulaminu Sejmu władze zrzeszeń parlamentarnych zobowiązane są podać do wiadomości Marszałka Sejmu składy osobowe zrzeszeń oraz ich regulaminy (statuty) wewnętrzne. Lakoniczność tej regulacji pozostawia poza zakresem unormowań regulaminowych szczegółowe określenie materii statutów wewnętrznych. Przyjąć jednak należy, że akty te mogą określać wyłącznie kwestie związane z funkcjonowaniem tych zrzeszeń i nie mogą być sprzeczne z prawem powszechnie obowiązującym oraz regulaminem Sejmu (wniosek wynikający z zasady legalizmu oraz zasady autonomii regulaminowej izb - art. 112 Konstytucji RP). Koniecznym elementem treści statutu jest określenie sposobu wyłaniania władz zrzeszenia. Wniosek taki wynika z analizy art. 8 ust. 7 regulaminu Sejmu, który obowiązek przekazania omawianych dokumentów nakłada expressis verbis na „władze” wymienionych w tym przepisie zrzeszeń, a także wiąże się z wymogiem praktycznym związanym z koniecznością ustalenia podmiotu reprezentującego zrzeszenie. Ponadto przepisy ustawy oraz przepisy regulaminu Sejmu wskazują, że koniecznym elementem struktury władz każdego zrzeszenia parlamentarnego jest funkcja przewodniczącego zrzeszenia, który uprawniony jest do jego reprezentacji (por. art. 15 ust. 1, art. 45 ust. 1, art. 136c ust. 2, art. 137 ust. 3, art. 143 ust. 2 regulaminu Sejmu oraz art. 18 ust. 3, 3a i 4 u.w.m.p.s.). Obowiązek ustanowienia takiej funkcji przez zrzeszenie nie przesądza wprawdzie związanych z nią szczegółowych praw i obowiązków, jednak postanowienia statutu nie mogą negować uprawnień przewodniczącego zrzeszenia wynikających z przywołanych wyżej przepisów regulaminu i ustawy. Podkreślić w tym kontekście należy, że pozycja przewodniczącego klubu poselskiego (parlamentarnego) jako członka Konwentu Seniorów oznacza, że z funkcją tą immanentnie wiąże się prawo reprezentowania klubu. W konsekwencji uznać trzeba, że postanowienia statutu powinny nie tylko normować strukturę władz zrzeszenia, ale zawierać też postanowienia określające tryb wyłaniania przewodniczącego zrzeszenia.

Obowiązek podania do wiadomości Marszałka Sejmu „składu” osobowego zrzeszenia mieści w sobie obowiązek informowania przez władze zrzeszenia o każdej zmianie tego składu. Oznacza to, że dla organów Sejmu źródłem informacji na temat zmiany składu osobowego zrzeszenia mogą być wyłącznie informacje przekazane przez jego władze. W przypadku utraty członkostwa źródłem 
tych informacji może być ponadto - adresowane do Marszałka Sejmu - oświadczenie posła, który wystąpił ze zrzeszenia (zwłoka władz zrzeszenia w poinformowaniu Marszałka Sejmu o wystąpieniu posła ze zrzeszenia nie może wpływać na jego status; przynależność do zrzeszenia parlamentarnego jest przywilejem, a nie obowiązkiem poselskim).

„Zawieszenie” członkostwa w klubie poselskim (parlamentarnym) nie powoduje per se utraty członkostwa w tym zrzeszeniu, a tym samym zmiany jego składu osobowego. Brak określenia w regulaminu Sejmu zasad odnoszących się do statusu posła, którego członkostwo zostało „zawieszone”, powoduje, że skutki takiego aktu postrzegać należy wyłącznie w sferze wewnętrznej danego zrzeszenia. „Zawieszony” poseł do momentu przekazania Marszałkowi Sejmu przez władze klubu lub przez zainteresowanego informacji o utracie członkostwa (względnie wystąpieniu z klubu) powinien być traktowany przez organy Sejmu jako członek danego zrzeszenia.

3. Ocena, która zakłada, że „zawieszenie” członkostwa w klubie poselskim (parlamentarnym) wywołuje wyłącznie skutki w zakresie wykonywania praw wynikających ze statutu danego klubu, przesądza odpowiedź na pytanie dotyczące konsekwencji „zawieszenia” dla wykonywania praw członka komisji sejmowej, której skład wyznacza zasada parytetu. Wątpliwość w tej materii dotyczy w szczególności Komisji do Spraw Unii Europejskiej (KSUE) oraz Komisji Etyki Poselskiej (KEP). W przypadku Komisji do Spraw Unii Europejskiej regulamin Sejmu nakazuje, by jej skład odzwierciedlał proporcjonalnie reprezentację w Sejmie klubów i porozumień liczących co najmniej 15 posłów (art. 148a ust. 2 - dopuszczalny wyjątek określa ust. 7). Jednocześnie w przypadku, gdy nastąpi zmiana liczebności klubu lub porozumienia $\mathrm{w}$ stopniu powodującym zmianę podziału miejsc w KSUE ze względu na szczegółowe zasady określone $\mathrm{w}$ art. 148a ust. 3 określające parytet albo w przypadku utworzenia nowego klubu lub porozumienia, Sejm zobowiązany jest dokonać wyboru nowego składu osobowego KSUE, przy czym uchwała o wyborze nowego składu osobowego KSUE jest równoznaczna z odwołaniem jej poprzedniego składu osobowego (art. 148a ust. 10).

Treść powołanego przepisu wiąże obowiązek dokonania przez Sejm zmian w składzie KSUE z utworzeniem nowego klubu lub porozumienia (przypadek irrelewantny z perspektywy tematu opinii) lub ze zmianą liczebności zrzeszeń uczestniczących w podziale miejsce $\mathrm{w}$ tej Komisji. Zmiana liczebności zrzeszenia biorącego udział w składzie Komisji może nastąpić poprzez przystąpienie nowych członków lub w wyniku utraty członkostwa przez członków dotychczasowych. "Zawieszenie” członkostwa nie aktualizuje obowiązku dokonania zmian w składzie KSUE, ponieważ nie prowadzi do zmiany liczebności klubu. Należy również pamiętać, że mandat członka KSUE, który utracił członkostwo w zrzeszeniu, które desygnowało go do składu Komisji, nie wygasa automatycznie. Zmiana przedstawiciela - w myśl zasad określonych w art. 148a ust. 12 re- 
gulaminu Sejmu - uzależniona jest od inicjatywy klubu lub porozumienia, które danego kandydata zgłosiło ${ }^{3}$.

Zasadę parytetu w odniesieniu do KEP wyraża art. 143 ust. 1 regulaminu Sejmu. W skład KEP wchodzą posłowie reprezentujący wszystkie kluby poselskie po jednym członku z każdego klubu (wyjątek określa art. 143 ust. 12). W razie utraty przez posła - członka KEP członkostwa w klubie jego członkostwo w Komisji wygasa (art. 143 ust. 14). Również w tym wypadku nie sposób uznać, by "zawieszenie" wykonywania praw związanych z członkostwem w macierzystym klubie przez członka KEP było tożsame $\mathrm{z}$ utartą członkostwa w tym zrzeszeniu. W konsekwencji należy uznać, że „zawieszenie” członkostwa w klubie poselskim (parlamentarnym) nie prowadzi do zmiany składu osobowego KEP.

\section{Podsumowanie}

Podsumowaniem opinii jest pogląd, że „zawieszenie” członkostwa w klubie poselskim (parlamentarnym) nie jest tożsame z utratą członkostwa w tym zrzeszeniu, czyli nie prowadzi do zmiany jego składu osobowego. Brak określenia w regulaminu Sejmu zasad odnoszących się do statusu posła, którego członkostwo zostało „zawieszone”, powoduje, że skutki takiego aktu postrzegać należy wyłącznie w sferze wewnętrznej danego zrzeszenia. „Zawieszony” poseł do momentu przekazania Marszałkowi Sejmu przez władze klubu lub przez zainteresowanego informacji o utracie członkostwa (względnie wystąpieniu z klubu) powinien być traktowany przez organy Sejmu jako członek danego zrzeszenia.

\section{Bibliografia}

Grajewski K., Uwagi do art. 17 [w:] Komentarz do ustawy o wykonywaniu mandatu posła i senatora, red. K. Grajewski, J. Stelina, P. Uziębło, Warszawa 2014.

3 Szerzej zob. W. Odrowąż-Sypniewski, Opinia prawna w sprawie członkostwa $w$ Komisji do Spraw Unii Europejskiej posła o statusie niezrzeszonym, z 2 czerwca 2016 r.; BAS-WAUiP 1051/16. 